\title{
Forage Quality of Winterhardy Lovegrasses
}

\author{
P.W. VOIGT, L.I. CROY, AND F.P. HORN
}

\section{Abstract}

Germplasm of Eragrostis curvula and E. lehmanniana was evaluated for in vitro dry matter disappearance (IVDMD), palatability (animal preference among genotypes), and forage vigor (weight/plant). Our objective was to determine if suficient genetic variation was present among relatively winterhardy genotypes to develop new lovegrass varieties with improved forage quality. The germplasm was divided into 4 types: curvula, conferta, short chloromelas (SC), and cold-hardy lehmann (CLE). Differences among types were significant for all characteristics studied. Differences within types were found also. The average IVDMD of the more stemmy CLE and SC types was higher than that of the more leafy curvula and conferta types. However, both CLE and SC types were less productive generally than curvula and conferta types and the palatability of CLE types was frequently lower than that of the other types. The more vigorous CLE types tended to be lower in IVDMD and palatability than less productive selections of that type. Chances of selecting an improved lovegrass variety directly from this germplasm are unlikely because few selections were superior to the weeping lovegrass controls. The best CLE and SC selections might be useful in a breeding program for improved forage quality if stemmyness can be decreased in their offspring while IVDMD is increased. Selections of the CLE type should not be widely planted until grazing evaluation proves them to be useful for animal production.

Weeping and boer lovegrass (Eragrostis curvula (Schrad) Nees) and lehmann lovegrass (Eragrostis lehmanniana Nees) are species that can be of value to cattlemen for conservation and for forage

Authors are research geneticist, USDA-ARS, P.O. Box 748, Temple, Texas 76503; professor, Agronomy Department, Oklahoma State University, Stillwater 74078; and formerly research animal nutritionist, USDA-ARS, P.O. Box 1199, El Reno, Okla. 73036 .

Contribution from the USDA, Agricultural Research Service, in cooperation with Oklahoma State University.

Manuscript accepted 21 October 1985. production. In some semiarid areas weeping lovegrass can be effectively used as intensively managed pasture. In more arid areas weeping, boer, and lehmann lovegrass have been used effectively for revegetation of rangelands.

Relatively poor forage quality is a factor seriously limiting the usefulness of weeping and lehmann lovegrass within their present areas of adaptation. Low summertime palatability limits the usefulness of lehmann lovegrass on Arizona rangelands (Cable 1971). Although good animal performance can be obtained from weeping lovegrass (Shoop et al. 1976, Cotter et al. 1983), weight gains are frequently less than on other warm-season grasses (Duble et al. 1971). This poorer animal performance was associated with low in vitro dry matter digestibility. Thus, a primary objective of our lovegrass improvement research is to increase digestibility. While palatability (relative animal preference) is not a major concern with grasses grown in pure stands, it is of concern in pastures or ranges where plant species are grown in mixtures (Voigt 1975).

The purpose of this research was to evaluate the variability for digestibility, palatability, and forage weight among relatively winterhardy selections of E. curvula and E. lehmanniana; and to examine the relationship among these and other plant characteristics.

\section{Materials and Methods}

Two experiments, initiated in 1969 and 1970 , were conducted at the U.S. Southern Great Plains Field Station, Woodward, Oklahoma. Experiment 1 was located on an Enterprise loam soil, and Experiment 2 on a Pratt fine sandy loam soil. Experiment 1 consisted of 70 entries planted in a randomized block design of 4 replications. Experiment 2 used a repeated simple lattice design of 4 replications for 169 entries. Except for the 4 weeping lovegrass controls ('Morpa', 'Ermelo', 'Renner', and common) entries were not duplicated in the 2 studies. Plots of 10 plants each were trans- 
planted in spring of the establishment year. Plant spacing was 1.1 $\mathrm{m}$ within and between plots. Because all entries were highly apomictic, variation between plants within a plot was very small.

Data were collected in the 2 years following establishment for both experiments. Experiment 1 was harvested in mid-May, early June, and late July 1970; and late May and late July 1971. Experiment 2 was harvested in mid-May, late June, and mid-August 1971; and early June and early July 1972. At the beginning of each data collection year, the dead foliage from the previous year's growth was removed by burning (1970) or mowing (1971 and 1972) about April 1. Ammonium nitrate fertilizer ( 30 to $40 \mathrm{~kg} \mathrm{~N} / \mathrm{ha}$ ) was applied following foliage removal in the spring and after "cleanup" mowing following each data collection period (harvest), except after the June 1971 regrowth harvest of experiment 2 . This amount was sufficient to produce growth without $\mathrm{N}$ deficiency symptoms. Because of iron deficiency problems in experiment 1, one replication was dropped and results are based on 3 replications. In exper- iment 2 iron deficiency symptoms appeared during summer regrowth periods in only a small part of the study. When this occurred, entire replications were foliar sprayed with iron sulfate. This treatment reduced chlorosis and increased topgrowth, thus reducing at least the visible effects of the deficiency.

One plant/plot (with plants on all sides) was harvested at a height of 8 to $10 \mathrm{~cm}$ to obtain an estimate of forage weight or vigor and to provide a sample for in vitro dry matter disappearance (IVDMD) analysis. Measures of IVDMD were obtained from forage samples dried at about 50 to $60^{\circ} \mathrm{C}$ and ground to pass a 2-mm screen. A modified Tilley-Terry technique (Monson et al. 1969) was used. Because relative values were of interest, IVDMD values were not adjusted to a common standard. Palatability scores were obtained on the 9 unharvested plants in each plot. Four to 19 steers had free access to all plants in experiment 1 , and to 2 of 4 replications at a time in experiment 2 . Grazing periods ranged from 3 to 7 days depending on the number of steers used and the

Table 1. Forage characteristics of lovegrass types and controls grown in experiment 1.

\begin{tabular}{|c|c|c|c|c|c|c|c|}
\hline \multirow[b]{2}{*}{ Character } & \multirow[b]{2}{*}{ Entries } & \multicolumn{2}{|c|}{1970} & \multicolumn{2}{|c|}{1971} & \multicolumn{2}{|c|}{$1970-71$} \\
\hline & & May & July & May & July & Mean & Range \\
\hline & & & & & & & mas \\
\hline IVDMD & $\begin{array}{l}\text { Curvula (19)1 } \\
\text { Conferta (12) } \\
\text { CLE (10) } \\
\text { Controls }\end{array}$ & $\begin{array}{l}51.4 \\
54.1 \\
56.4 \\
50.7\end{array}$ & $\begin{array}{l}43.0 \\
40.6 \\
43.4 \\
43.4\end{array}$ & $\begin{array}{l}32.9 \\
33.2 \\
36.1 \\
34.0\end{array}$ & $\begin{array}{l}32.1 \\
29.9 \\
30.0 \\
31.8\end{array}$ & $\begin{array}{l}39.1 \\
38.4 \\
40.4 \\
39.4\end{array}$ & $\begin{array}{l}35.5-42.6 \\
36.5-40.3 \\
37.4-45.4 \\
35.5-42.6[2.8]^{3}\end{array}$ \\
\hline Palatability & $\begin{array}{l}\text { Curvula } \\
\text { Conferta } \\
\text { CLE } \\
\text { Controls }\end{array}$ & $\begin{array}{l}2.7 \\
4.7 \\
4.1 \\
2.8\end{array}$ & $\begin{array}{l}2.5 \\
3.0 \\
1.0 \\
2.7\end{array}$ & $\begin{array}{l}2.0 \\
3.2 \\
3.0 \\
2.5\end{array}$ & $\begin{array}{l}2.2 \\
2.7 \\
0.8 \\
2.4\end{array}$ & $\begin{array}{l}2.3 \\
3.3 \\
2.0 \\
2.6\end{array}$ & $\begin{array}{l}1.4-3.2 \\
3.2-3.5 \\
1.6-2.4 \\
18-3.2[0.4]\end{array}$ \\
\hline Forage weight & $\begin{array}{l}\text { Curvula } \\
\text { Conferta } \\
\text { CLE } \\
\text { Controls }\end{array}$ & $\begin{array}{r}96 \\
47 \\
27 \\
105\end{array}$ & $\begin{array}{l}131 \\
146 \\
140 \\
142\end{array}$ & $\begin{array}{l}192 \\
133 \\
107 \\
207\end{array}$ & $\begin{array}{l}222 \\
226 \\
234 \\
242\end{array}$ & $\begin{array}{l}265 \\
146 \\
138 \\
178\end{array}$ & $\begin{array}{c}122-222 \\
118-164 \\
79-178 \\
154-197[29]\end{array}$ \\
\hline
\end{tabular}

IValue in parentheses is the number of entries.

${ }^{2}$ Controls were the curvula types Ermelo, Morpa, and common.

${ }^{3}$ Value in brackets is the L.S.D. (0.05) for comparison of individual entries.

4Palatability scored on a scale of $0=0-10 \%$ and $5=90-100 \%$ of available forage consumed.

Table 2. Forage characteristics of lovegrass types and controls grown in experiment 2.

\begin{tabular}{|c|c|c|c|c|c|c|c|}
\hline \multirow[b]{2}{*}{ Character } & \multirow[b]{2}{*}{ Entries } & \multicolumn{2}{|c|}{1971} & \multicolumn{2}{|c|}{1972} & \multicolumn{2}{|c|}{$1971-72$} \\
\hline & & May & Aug. & June & July & Mean & Range \\
\hline IVDMD & $\begin{array}{l}\text { Curvula (103)! } \\
\text { Conferta (9) } \\
\text { CLE (22) } \\
\text { SC (19) } \\
\text { Controls }^{2}\end{array}$ & $\begin{array}{l}33.9 \\
34.9 \\
36.7 \\
36.4 \\
33.0\end{array}$ & $\begin{array}{l}31.8 \\
30.0 \\
32.3 \\
32.8 \\
32.1\end{array}$ & $\begin{array}{l}54.6 \\
53.0 \\
57.0 \\
55.2 \\
54.9\end{array}$ & $\begin{array}{l}58.7 \\
57.1 \\
59.2 \\
59.7 \\
59.8\end{array}$ & $\begin{array}{l}44.8 \\
43.7 \\
46.3 \\
46.0 \\
45.0\end{array}$ & $\begin{array}{l}41.4-47.8 \\
42.8-45.2 \\
43.4-48.9 \\
44.4-49.8 \\
43.6-46.1[3.0]^{3}\end{array}$ \\
\hline Palatability & $\begin{array}{l}\text { Curvula } \\
\text { Conferta } \\
\text { CLE } \\
\text { SC } \\
\text { Controls }\end{array}$ & $\begin{array}{l}1.6 \\
2.0 \\
1.3 \\
2.2 \\
1.4\end{array}$ & $\begin{array}{l}2.2 \\
2.4 \\
1.0 \\
1.8 \\
2.2\end{array}$ & $\begin{array}{l}1.6 \\
2.5 \\
1.3 \\
1.7 \\
1.6\end{array}$ & $\begin{array}{l}2.8 \\
3.5 \\
2.3 \\
3.6 \\
3.0\end{array}$ & $\begin{array}{l}2.1 \\
2.7 \\
1.4 \\
2.3 \\
2.1\end{array}$ & $\begin{array}{l}1.1-3.4 \\
2.5-2.9 \\
0.9-2.2 \\
1.2-3.2 \\
1.7-2.6[0.5]\end{array}$ \\
\hline Forage weight & $\begin{array}{l}\text { Curvula } \\
\text { Conferta } \\
\text { CLE } \\
\text { SC } \\
\text { Controls }\end{array}$ & $\begin{array}{r}159 \\
125 \\
93 \\
107 \\
184\end{array}$ & $\begin{array}{l}161 \\
171 \\
146 \\
164 \\
174\end{array}$ & $\begin{array}{l}275 \\
249 \\
162 \\
210 \\
257\end{array}$ & $\begin{array}{r}123 \\
158 \\
99 \\
108 \\
121\end{array}$ & $\begin{array}{l}180 \\
180 \\
129 \\
151 \\
184\end{array}$ & $\begin{array}{r}59-226 \\
158-198 \\
73-209 \\
48-185 \\
166-200[36]\end{array}$ \\
\hline
\end{tabular}

IValue in parentheses is the number of entries.

${ }^{2}$ Controls were the curvula types Morpa, Ermelo and common, and the robusta type Renner.

Value in brackets is the L.S.D. (0.05) for comparison of individual entries.

Palatability scored on a scale of $0=0-10 \%$ and $5=90-100 \%$ of available forage consumed. 
amount of forage available. Grazing periods were ended when the least palatable entries showed some signs of animal use and the most palatable had been consumed to a 8 to $13-\mathrm{cm}$ stubble height. Palatability was scored daily on each plant as a percentage of a vailable forage consumed (scale 0 to 5 with $0=0$ to $10 \%$ and $5=90$ to $100 \%$ ). Palatability data reported here are based on plot means over all plants and days for a grazing period. Because of physical size, experiment 2 was split in half for sampling and scoring. Thus, replications 1 and 2 were sampled and grazed first followed by replications 3 and 4 . Any effects caused by this small difference in age of forage among replications were ignored. Winter survival was scored on a scale of 0 to $5(0=0$ to $10 \%$ and $5=90$ to $100 \%$ of each plant alive) maturity at first harvest (experiment 2 ), on a scale of $0=$ preboot stage to $5=$ post anthesis, and production of flowering culms at regrowth harvests (experiment 2) on a scale of 0 $=$ none to 4 = very many.

Eragrostis curvula is an apomictic complex and its taxonomic classification is difficult and sometimes confusing. To differentiate among similar forms, the use of agricultural types was proposed (Leigh and Davidson 1968). Several of the types were not very winterhardy and were not well represented in the selections studied at Woodward. Despite the fact that the types intergrade (Jacobs, 1982), division into morphological types is useful in characterizing the available germplasm. Four types were used.

1. Curvula, typical weeping lovegrass of the United States, with a predominance of mostly basal, long-narrow leaves over stems, e.g., Ermelo or Morpa.

2. Conferta, typical boer lovegrass of the United States, with a predominance of leaf over stem but leaves and plants shorter than curvula and a short, compact inflorescence e.g., 'A-84' or 'Catalina'.

3. Cold-hardy lehmann (CLE), identified as E. lehmanniana in the United States but coarser, more vigorous, and more winterhardy than typical lehmann lovegrass. The plant is stemmy and tending decumbent with culm leaves relatively more important than basal leaves. 'Cochise' lovegrass (Eragrostis lehmanniana Nees $X$ Eragrostis trichophora Coss. \& Dur.) is similar to this type.

4. Short chloromelas (SC), similar to CLE in general appearance but shorter and with finer stems. None released in the United States. Selections that were seriously winter injured or did not fit into these types are not discussed in this paper.

\section{Results and Discussion}

\section{Performance}

Significant differences were detected among lovegrass types for all characters studied. Surprisingly, the more stemmy CLE and SC types averaged higher in IVDMD than the leafier curvula and conferta types (Tables 1 and 2). This was true especially at the first harvest but only part of the time at regrowth harvests. Variation in IVDMD within the CLE type (both experiments) and SC type (experiment 2) was similar to that within the curvula type, although the actual values for the CLE and SC selections were higher. On average the conferta type was lowest in IVDMD. Few of the experimental selections exceeded the controls in digestibility. Thus, the potential of this germplasm for improving lovegrass IVDMD appears small.

In both studies conferta types were superior in average palatability (Tables 1 and 2), although in experiment 2 some curvula types were preferred over some conferta types. The superiority of the conferta type was observed at all harvests except for the less mature harvests in experiment 2 (1971 May and 1972 July), when the SC type was preferred. When growth was more mature, the conferta type was clearly preferred. The CLE selections studied in experiment 1 were more palatable when grazed at an immature stage than curvula types but were always the least palatable lovegrass in experiment 2 or when grazed as regrowth.

Curvula types showed the widest range in palatability in both studies. However, few selections in any type exceeded the best control (Morpa) in palatability over all harvests. Leigh (1961) and Johnston and Aveyard (1977) both suggest that the curvula type is among the least palatable of the lovegrass. Our results, for relatively winterhardy germplasm, suggest that this is not always true. It must be recognized, however, that their germplasm was not limited to winterhardy types. The differences in results could be caused by differences in germplasm evaluated as well as differences in procedures.

Differences among types in forage weight were greatest at first harvest in each year, and curvula types produced more than all other types at that time (Tables 1 and 2). In regrowth harvests, the conferta types were the most productive. This result may be somewhat deceiving, because the conferta type exhibited a narrow range in productivity relative to the other types. Thus, relatively high average production was assessed because the small sample of conferta types studied over both experiments contained no selections with very poor vigor. In contrast, CLE and SC selections from experiment 2 contained selections that averaged less than 100 $\mathrm{g} /$ plant. Few if any selections were superior to the controls when data were averaged over more than 1 harvest. Thus, chances of making selections from this germplasm that would be higher yielding than present cultivars appear slight. Our results are consistent with those reported by Leigh (1967) in that the curvula type can be among the most productive.

\section{Relationships Among Harvests and Years}

In general, interactions between entries and harvests or entries and years were significant $(0.05)$ for most comparisons. Those for IVDMD tended to be smaller than those for palatability or forage

Table 3. Interharvest and interyear correlation coefifieients, experiment 1.

\begin{tabular}{llccc}
\hline \hline & & \multicolumn{2}{c}{ Between harvests } & \\
\cline { 2 - 4 } Character & Type & 1970 & 1971 & Between years \\
\hline IVDMD (\%) & Curvula & $0.78^{* * 2}$ & 0.29 & 0.42 \\
& Conferta & -0.37 & -0.08 & 0.07 \\
& CLE & -0.17 & 0.30 & 0.46 \\
Palatability1 & Curvula & -0.15 & 0.36 & $0.55^{*}$ \\
& Conferta & 0.33 & -0.35 & 0.04 \\
& CLE & $-0.76^{*}$ & $-0.63^{*}$ & $0.75^{*}$ \\
Forage weight & Curvula & 0.17 & 0.32 & $0.82^{* *}$ \\
(g/plant) & Conferta & $0.68^{*}$ & -0.18 & $0.61^{* *}$ \\
& CLE & -0.17 & 0.43 & $0.91^{* *}$ \\
\hline
\end{tabular}

${ }^{1}$ Palatability scored on a scale of $0=0-10 \%$ to $5=90-100 \%$ of available forage consumed.

2 Values followed by * and ** significantly different from 0 at the 0.05 and 0.01 level of probability, respectively.

weight. This was not due to greater consistency from harvest to harvest or year to year for IVDMD compared to the other characters, but rather to the low variation among entries observed for IVDMD, relative to experimental error. The usually higher correlation coefficients between harvests and years for palatability and for forage weight than for IVDMD (Tables 3 and 4) support this conclusion.

In experiment 1 few between-harvest correlation coefficients were statistically significant (Table 3 ). Only the negative relationship between first and regrowth harvest palatability for the CLE type was significant in both years. However, that relationship was not observed in experiment 2 (Table 4). Relative ranking between harvests was more consistent for curvula and SC types than for the others in experiment 2. Thus, harvest had less of an effect on relative performance of those types than on the CLE and conferta types.

Relative rankings between years were more consistent in experiment 2 than experiment 1 (Tables 3 and 4). In general, betweenyear correlation coefficients were larger than those for between harvest. Thus, rankings were more consistent from year to year than from harvest to harvest. The larger mean squares for entry- 
Table 4. Interharvest and interyear correlation coefifients, experiment 2.

\begin{tabular}{lllcc}
\hline & & \multicolumn{2}{c}{ Between harvests } & \\
\cline { 2 - 4 } Character & Type & 1970 & 1971 & Between years \\
\hline IVDMD (\%) & Curvula & 0.08 & $0.72^{* * 2}$ & $0.41^{* *}$ \\
& Conferta & 0.07 & -0.02 & $0.77^{*}$ \\
& CLE & 0.33 & $0.50^{*}$ & 0.31 \\
& SC & $0.51^{*}$ & $0.75^{* *}$ & 0.03 \\
Palatability1 & Curvula & $0.41^{* *}$ & $0.63^{* *}$ & $0.82^{* *}$ \\
& Conferta & $-0.64^{*}$ & -0.06 & $0.67^{*}$ \\
& CLE & -0.32 & 0.19 & $0.87^{* *}$ \\
& SC & $0.83^{* *}$ & 0.22 & $0.83^{* *}$ \\
Forage weight & Curvula & $0.66^{*}$ & $0.83^{* *}$ & $0.89^{* *}$ \\
(g/plant) & Conferta & -0.47 & $0.84^{* *}$ & $0.88^{* *}$ \\
& CLE & $0.51^{*}$ & $0.92^{* *}$ & $0.94^{* *}$ \\
& SC & $0.63^{* *}$ & $0.63^{* *}$ & $0.68^{* *}$ \\
\hline
\end{tabular}

'Palatability scored on a scale of $0=0-10 \%$ to $5=90-100 \%$ of available forage consumed.

${ }^{2}$ Values followed by * and ** significanlty different from 0 at the 0.05 and 0.01 level of probability, respectively. by-harvest interactions than for entry-by-year interactions from the analysis of variance (not shown) support that conclusion.

\section{Relationships Between Characters}

In the CLE type at first harvest, IVDMD decreased as forage weight increased (Tables 5 and 6). This is apparently not a reflection of maturity differences because maturity was not related to forage weight or IVDMD in this type. Palatability and forage weight were negatively associated at first harvest, especially for the curvula and conferta types. Palatability also declined as maturity increased for all types (Table 6). Increased (early) maturity and greater forage weight were closely related only for the conferta type. For the other types, first harvest maturity was more important in determining palatability than forage weight.

In regrowth harvests, IVDMD and palatability were positively correlated only in the curvula type. Other trends relative to IVDMD were not consistent across years or experiments. Selections tending to be high in regrowth forage weight tended to be low in palatability, especially for the CLE and to a lesser extent for the curvula types. Regrowth palatability was also negatively related to number of flowering culms for both those types and for the SC type. Because number of heads was not related to forage weight in the SC type, it appears likely that a large number of heads may be more detrimental to palatability than plant size (forage weight). Thus, for the curvula and especially for the CLE type, the negative

Table 5. Between character correlation coefinclents for experiment 1.'

\begin{tabular}{|c|c|c|c|c|c|c|c|}
\hline \multirow[b]{2}{*}{ Character } & \multirow[b]{2}{*}{ Type } & \multicolumn{2}{|c|}{ IVDMD } & \multicolumn{2}{|c|}{ Palatability } & \multicolumn{2}{|c|}{ Forage weight } \\
\hline & & 1970 & 1971 & 1970 & 1971 & 1970 & 1971 \\
\hline IVDMD (\%) & $\begin{array}{l}\text { Cuvula } \\
\text { Conferta } \\
\text { CLE }\end{array}$ & & & $\begin{array}{l}0.37 \\
0.10 \\
0.71 * 2\end{array}$ & $\begin{array}{r}0.15 \\
-0.13 \\
0.10\end{array}$ & $\begin{array}{r}0.01 \\
-0.21 \\
-0.58\end{array}$ & $\begin{array}{l}-0.16 \\
-0.15 \\
-0.66^{*}\end{array}$ \\
\hline Palatability $^{3}$ & $\begin{array}{l}\text { Curvula } \\
\text { Conferta } \\
\text { CLE }\end{array}$ & $\begin{array}{c}0.59 * \\
-0.08 \\
0.39\end{array}$ & $\begin{array}{l}0.17 \\
0.22 \\
0.44\end{array}$ & & & $\begin{array}{l}-0.72^{*} \\
-0.06 \\
-0.87^{*}\end{array}$ & $\begin{array}{l}-0.31 \\
-0.65^{*} \\
-0.38\end{array}$ \\
\hline $\begin{array}{l}\text { Forage weight } \\
\text { (g/plant) }\end{array}$ & $\begin{array}{l}\text { Curvula } \\
\text { Conferta } \\
\text { CLE }\end{array}$ & $\begin{array}{r}0.08 \\
-0.04 \\
-0.49\end{array}$ & $\begin{array}{r}-0.02 \\
0.08 \\
-0.32\end{array}$ & $\begin{array}{l}-0.03 \\
-0.11 \\
-0.58\end{array}$ & $\begin{array}{l}-0.65^{* *} \\
-0.44 \\
-0.79 * *\end{array}$ & & \\
\hline
\end{tabular}

IValues above and to the right are for the first harvest, those below and to the left for the regrowth harvests.

$2 *, *$ significant at the 0.05 and 0.01 levels, respectively.

3Palatability on a scale of $0=0-10 \%$ and $5=90-100 \%$ of available forage consumed.

Table 6. Between character correlation coeficients for experiment 2.1

\begin{tabular}{|c|c|c|c|c|c|c|c|c|}
\hline \multirow[b]{2}{*}{ Character } & \multirow[b]{2}{*}{ Type } & \multicolumn{2}{|c|}{ IVDMD } & \multicolumn{2}{|c|}{ Palatability } & \multicolumn{2}{|c|}{ Forage weight } & \multirow{2}{*}{$\frac{\text { Maturity }}{1971}$} \\
\hline & & 1971 & 1972 & 1971 & 1972 & 1971 & 1972 & \\
\hline$\overline{\text { IVDMD (\%) }}$ & $\begin{array}{l}\text { Curvula } \\
\text { Conferta } \\
\text { CLE } \\
\text { SC }\end{array}$ & & & $\begin{array}{r}0.18 \\
0.42 \\
-0.16 \\
0.20\end{array}$ & $\begin{array}{l}0.48 * * 2 \\
-0.10 \\
-0.30 \\
0.38\end{array}$ & $\begin{array}{l}-0.02 \\
-0.01 \\
-0.51^{*} \\
-0.28\end{array}$ & $\begin{array}{c}0.00 \\
0.08 \\
-0.65^{* *} \\
-0.53^{*}\end{array}$ & $\begin{array}{r}-0.08 \\
-0.44 \\
0.26 \\
-0.22\end{array}$ \\
\hline Palatability ${ }^{3}$ & $\begin{array}{l}\text { Curvula } \\
\text { Conferta } \\
\text { CLE } \\
\text { SC }\end{array}$ & $\begin{array}{c}0.21^{*} \\
0.55 \\
0.20 \\
-0.07\end{array}$ & $\begin{array}{c}0.67 * * \\
-0.33 \\
0.32 \\
0.24\end{array}$ & & & $\begin{array}{l}-0.42^{* *} \\
-0.75^{*} \\
-0.12 \\
0.03\end{array}$ & $\begin{array}{c}-0.39^{* *} \\
-0.90^{* *} \\
0.21 \\
0.02\end{array}$ & $\begin{array}{l}-0.82^{* *} \\
-0.87^{* *} \\
-0.90^{* *} \\
-0.97^{* *}\end{array}$ \\
\hline $\begin{array}{c}\text { Forage weight } \\
\text { (g/plant) }\end{array}$ & $\begin{array}{l}\text { Curvula } \\
\text { Conferta } \\
\text { CLE } \\
\text { SC }\end{array}$ & $\begin{array}{c}0.00 \\
-0.02 \\
-0.29 \\
-0.23\end{array}$ & $\begin{array}{c}0.08 \\
0.02 \\
-0.78^{* *} \\
-0.60^{* *}\end{array}$ & $\begin{array}{l}-0.40^{* *} \\
-0.57 \\
-0.71^{* *} \\
-0.23\end{array}$ & $\begin{array}{l}-0.06 \\
-0.45 \\
-0.44^{*} \\
-0.01\end{array}$ & & & $\begin{array}{l}0.29 * * \\
0.88 * * \\
-0.09 \\
-0.01\end{array}$ \\
\hline No. heads ${ }^{4}$ & $\begin{array}{l}\text { Curvula } \\
\text { Conferta } \\
\text { CLE } \\
\text { SC }\end{array}$ & $\begin{array}{r}0,12 \\
0.08 \\
-0.28 \\
0.03\end{array}$ & $\begin{array}{c}0.05 \\
-0.06 \\
-0.47^{*} \\
0.04\end{array}$ & $\begin{array}{l}-0.44^{* *} \\
-0.53 \\
-0.59 * * \\
-0.62^{* *}\end{array}$ & $\begin{array}{l}-0.07 \\
-0.50 \\
-0.75 * * \\
-0.81 * *\end{array}$ & $\begin{array}{l}0.22^{*} \\
0.02 \\
0.72^{* *} \\
0.01\end{array}$ & $\begin{array}{l}0.43^{* *} \\
-0.12 \\
0.60^{* *} \\
0.14\end{array}$ & \\
\hline
\end{tabular}

IValues above and to the right are for the first harvest, those below and to the left for the regrowth harvests.

$2 *, * *$ significant at the 0.05 and 0.01 levels, respectively.

3alatability on a scale of $0=0-10 \%$ and $5=90-100 \%$ of available forage consumed.

4 Number of flowering culms on a scale of $0=$ none to $4=$ very many.

SMaturity on a scale of $0=$ preboot stage to $5=$ post anthesis with inflorescence branches fully spread. 
relationship between palatability and forage weight could be in part the indirect result of the positive relationship between forage weight and number of heads.

Winter survival scores were not significantly correlated with IVDMD in experiment 1 . However, in experiment 2 curvula selections that were higher in IVDMD tended to be lower in survival $(r=$ $-0.21^{*}$ to $-0.40^{* *}$ ). For the other types, the relationship was not consistent though they tended to be negative also for the SC type ( $r$ $=-0.20$ to $-0.70^{* *}$ ). Palatability also tended to be negatively related to winter survival, especially within the curvula type at first harvest $\left(r=-0.48^{* *}\right.$ to $\left.-0.78^{* *}\right)$ over both experiments. Correlation coefficients at regrowth harvests were less consistent but were negative when significant for the curvula type.

\section{Conclusions}

Selection for improved forage quality within this relatively winterhardy germplasm does not appear promising. Few experimental selections were better than the controls in any characteristic studied. Some CLE and SC selections appeared superior for IVDMD despite their stemmyness when mature, but these were some of the least palatable of the selections evaluated. Furthermore, the CLE selections that were highest in IVDMD tended to be lower in forage production. Thus, from a forage standpoint, the CLE type does not appear particularly useful to the livestock producer. Because it can be hybridized with sexual forms of $E$. curvula (Voigt and Burson 1983), it may be useful for improving IVDMD of weeping lovegrass if stemmyness can be reduced in its offspring while IVDMD is increased.

Other sources of higher IVDMD are needed if forage quality in $E$. curvula is to be improved. These extensive evaluations, conducted with a broad array of relatively winterhardy germplasm, suggest that the necessary genes will probably not be found within the most winterhardy E. curvula germplasm.

These results suggest also that caution should be used in planting CLE type selections on rangelands because of their extremely poor palatability when mature. Although the cultivar Cochise was not included in these studies, it is very similar to the CLE type. The authors believe that forage quality and animal grazing studies are essential before Cochise is widely planted.

\section{Literature Cited}

Cable, D.R. 1971. Lehmann lovegrass on the Santa Rita Experimental Range, 1937-1968. J. Range Manage. 24:17-21.

Cotter, P.F., B.E. Dahl, and G. Scott. 1983. Utilization of a short duration grazing system for renovation and management of weeping lovegrass (Eragrostis curvula) in the Rolling Plains of Texas. p. 24-30. In: Proc. Forage and Grassl. Conf., Amer. Forage and Grassland Counc., Lexington, Ken.

Duble, R.L., J.A. Lancaster, and E.C. Holt. 1971. Forage characteristics limiting animal performance on warm-season perennial grasses. Agron. J. 63:795-798.

Jacobs, S.W.L. 1982. Classification in the Eragrostis curvula complex in Australia. Aust. Plant Intro. Rev. 15:5-14.

Johnston, W.H., and J.M. Aveyard. 1977. Testing and selection of African lovegrass (Eragrostis curvula) for soil conservation in Southwestern New South Wales. Aust. Plant Intro. Rev. 12:27-40.

Leigh, J.H. 1961. The relative palatability of various varieties of weeping lovegrass (Eragrostis curvula (Schrad.) Nees). J. Brit. Grassl. Soc. 16:135-140.

Leigh, J.H. 1967. Comparisons between strains of Eragrostis curvula in South Africa. Exp. Agric. 3:327-335.

Leigh, J.H., and R.L. Davidson. 1968. Eragrostis curvula (Schrad.) Nees and some other African lovegrass. Aust. Plant Intro. Rev. 5:21-44.

Monson, W.G., R.S. Lowrey, and I. Forbes. 1969. In vivo nylon bag vs. two-stage in vitro digestion: Comparison of two techniques for estimating dry-matter digestibility of forages. Agron. J. 61:587-589.

Shoop, M., E.H. Mcllvain, and P.W. Voigt. 1976. Morpa weeping lovegrass produces more beef. J. Range Manage. 29:101-103.

Voigt, P.W. 1975. Improving palatability of range plants, p. 23-49. In: R.S. Campbell and C.H. Herbel (eds.). Improved range plants. Range Symp. Ser. 1. Soc. Range Manage., Denver, Colo.

Voigt, P.W., and B.L. Burson. 1983. Breeding of apomictic Eragrostis curvula. p. 160-162.In: J.A. Smith and V.W. Hays (eds.). Proc. 14th Internat. Grassl. Congr. Westview Press, Boulder, Colo.

\section{Color Photos}

Although it is not feasible financially for us to offer illustrations in color in the body of the journal, we have investigated the possibility of handling groups of color articles in one segment of the journal. Such a project would involve additional expense for page charges and possibly some delay in publication, but might bring costs within the capability of authors to whom color photographs are essential. Authors who may be considering this should contact the editor: 2760 West Fifth Avenue, Denver, Colo. 80204; (303) 571-0174. 